摘するような疑問の余地を残している.鈴木はこの点を 考虑に入れながら，それらの ${ }^{14} \mathrm{C}$ 年代を基にして検定曲 線を引いているが，むしろ萀めたいのは，町田・鈴木 （1971）が下末吉・武蔵野ローム層中から発見した黒曜 石について，水和層の測定を試みることである. これら の黑曜石は，火山灰とともに噴出降下したるのとして， そのフィション・トラック年代はテフラの年代を与える ものとしている. そうであるならば，その同じ黒曜石の 表面に形成されている水和層の厚さは当然, その黑曜石 のフィション・トラック年代と対応するものである。そ の年代は ${ }^{14} \mathrm{C}$ 年代よりは遙かに古いけれども, 検定曲線 作成の基準としては極めて有効であると思われる.

そうなると，ここでフィション・トラック年代の信頼 性について，一言触れておかなければならない，この年 代測定法については, 特に ${ }^{238} \mathrm{U}$ の自発核分裂率の值に対 して，これを疑問視する向きがある.というのは，この 常数の決定の基準として, Fleischer, Price (1964) はフ イション・トラックを測定した鉱物の年代を， K-Ar 法 や $\mathrm{Rb}-\mathrm{Sr}$ 法を用いて決定しているが，特に $\mathrm{K}-\mathrm{Ar}$ 法自 体の信頼性に関して問題があるからである.もっとも， ${ }^{238 U}$ の崩壊率はこれだけから算定されたものではなく, 合成雲母と天然ウランを用いた実験結果も参酌されてい る.しかし，いずれにしても， ${ }^{238}$ Uの崩壊率が正しいか どうかは，それを用いて算出されるフィション・トラッ ク年代の信頼性に対して，直接影響するのである.

そこで，この問題について，一つの解答を与えると思 われる実験例を紹介しておきたい，それは Brill, Fleischer, Price, Walker (1964) によって行なわれた. 特殊 ガラス器のフィション・トラック年代の測定である. 前 世紀の中頃から欧米では, 発色剂としてウランを含んだ
ガラス器が作られるようになったが，このものは美麗な 黄緑色を呈し, 紫外線が当ると輝やかしい緑色の䖝光を 発するという．作製年代のわかっている，このようなウ ランガラス器 5 箇について, 従来の ${ }^{288} \mathrm{U}$ 崩壊率を用いて フィション・トラック年代が測定された.その結果をみ る, とウラン含有量 $0.61 \% ， 1850 \sim 1860$ 年作成のガラ ス器のフィション・トラック年代は $1840 \pm 20$ 年, 同じ く U 0.44\%, 19 世紀第 4 四半世紀のガラス器で 1860 \pm 18 年, $\mathrm{U} 2.5 \%, 1925 \sim 28$ 年作成のものが $1924 \pm 7$ 年, U1.21\%, 1939 年 1 月以前作の器で $1938 \pm 6$ 年, $\mathrm{U} 5,3 \%, 1943$ 年 12 月作のもの $1945 \pm 4$ 年, U1.56 $\%, 1912$ 年頃作成のものが $1914 \pm 20$ 年となっている. これらのフィション・トラック年代は, いずれもガラス 器作成年代と極めてよく一致している，とみることがで きる.このことは, 一方では年代の算出に用いられた ${ }^{238}$ U崩壊率が妥当な值であるばかりでなく, その崩壊率 決定の基となった $\mathrm{K}-\mathrm{Ar}$ 年代もまた，信頼に足ること を意味するものといえる.

\section{引用交献}

Brill, R. H., R. L. Fleischer, P. B. Price and R. M. Walker (1964) The fission-track dating of man-made glasses: Preliminary results. J. Glass Studies, 7, 151 $-6$.

Fleischer, R. L. and P. B. Price (1964) Decay constant for spontaneous fission of U ${ }^{238}$. Phys. Rev., 133, B63-64.

勝井義雄 ·近堂祐弘 (1963) 白滝団体研究会編, 白滝遺 跡の研究, 49-54.

Michels, J. M. (1967) Archeology and dating by hydration of obsidian. Science, 154, 211-214.

（東京大学理学部人類学教室）

\title{
論評に対する原著者の回答 Authors' Replies to the Comments
}

\section{1. 小林逴夫氏の睔評に答えて}

南関東先土器時代の代表遺跡である武蔵野の野川遺跡 と相模野の月見野遺跡に関して，テフロクロノロジーに よる対比, 編年と考古学 (石器の型式学) によるそれと の相違は，本文にもまた小林論評にも記されているが, 簡単に図示すると，第 1 四のようである. すなわち，立 川ローム中部に括いてナイフ型石器の出土層位とテフラ

\section{町田洋 \\ Hiroshi MACHIDA}

の鍵層とが交叉する.これに関して，小林論評はテフロ クロノロジーの側で再検討し対比の論拠を明確にせよと 望えでいる. 筆者らは本文のま光がきにものべたよう に, 人類史之自然の变遷史とのかかわりに関する第四紀 末期の諸問題の解明には，多くの異なった方向から接近 をしていき，拈互いに足らないところを補ない，誤りを 正し合う必要があると考えている. この意味で，テフロ 
クロノロジーと考古学の対比結果のちがいの意義を検討 するのは，その本旨に沿うものであり，きわめて有意義 であると考える．まず互いに結論を出す過程に誤りがな かったか，両者のちがいが本質的なものかどうかを検討 するべきであることはいうまでもない.

さて，テフロクロノロジーの観点からの結論では，第 1 図の鍵層（とくに TnP） およびその層準の認定には いまのところ誤りは，見出すことができない，したがっ て, 出土石器の型式に関する判断に誤りがなければ，両 接近法のもたらした隔りは，依然として大きいといえる。

立川ローム中部を占める丹沢パミス (ガラス質火山灭) を，相模野から武蔵野にかけて追跡・対比した理由は， 本文でものべられているが，とくに強調したいのは，こ のテフラがきわめて 特徵的な 組成をもつという点であ

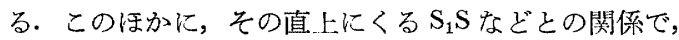
野外で追跡できるという点もある．立川ローム層はよく 知られているように，斑晶鉱物はもっぱらかんらん石， 輝石，鉄鉱物，斜長石などからなり，玄武岩質のスコリ ア層がその大部分を占める。ここでのべた丹沢パミスは ほとえぞ火山ガラスのみからなるきわめて特異な火山灰 である.火山ガラスそのものは，別の層準でもわずかな がら認められるが, 相模野, 武蔵野で TnP の層準とし た部分は，特徵のある火山ガラスの密集帯である.そし てその火山ガラスの屈折率がどこでもほぼ 1.500 でかな り珪長質であること，無色透明で新鮮なこと，気泡を含 夕形状に特徴があり，しかも随伴鉱物（しそ輝石，普通 輝石，角閃石，鉄鉱物など）に共通する点のあることな どの特徵をもち，近接する層準のテフラにこれと類似す るガラスはなだ見出されていない，すでに，貝塚(1958) の武蔵野における発見につづいて，加藤(1962) も，東海 地方の台地上のクロボク土に，似た火山ガラスのあるこ とを指摘している. 立川ローム中の他の火山ガラス供給 層について, 今後相模野以西で詳しい調査を行なう必要 はあるが,いまのところ,近接した他の層準に TnP と全

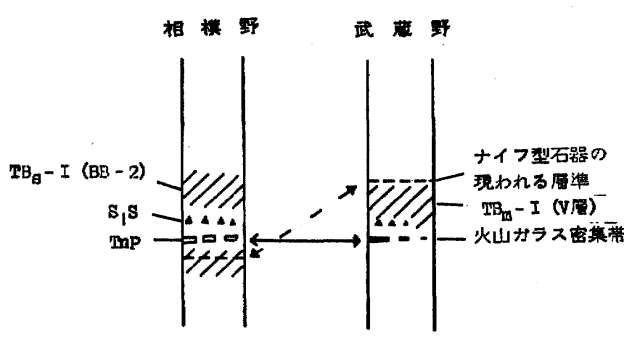

第 1 図 実線の矢印はテフラによる対比. 破線の矢 印は石器型式による対比. 斜線部は暗色帯.
く類似した，しかし別のガラス質火山灰は認められてい ない.したがって，現段階では，TnP は富士，愛鷹周辺 から武蔵野にいたる広域にわたって，立川ローム中部の きわめて重要な指示層と認めることができるのである. 小林論評は, 相模野での立川ローム下限の位置を, TnP の下位にある波状の鄸乱帯においた筆者の対比か ら今回の対比への変更について論理的プロセスを示せと のベている. それは前説汇おいては, 相模野におけるい わゆる波状の擾乱帯が，武蔵野における立川口ーム・武 蔵野ローム境界(いうまでもなく関東ローム (1958) によ って規定されれたクラック帯) ときわめて酷似した岩相 を示したこと，およびそれより上の暗色帯の発現状態が 武藏野における立川口ーム中の上・下の暗色帯のそれと 似ていたことに判断の材料を求めたからである. そして こうした前説を訂正し相模野における両ローム境界層を より下方へもってくるように改めざるを得なくなったの は，従来報告のなかった丹沢周辺や富士東麓で特異な火 山ガラス質パミスを発見し，それの東方への追跡によっ て, 従来武藏野で貝塚により指摘されたガラス密集帯に つづくことを確かめ，それをクラック带あるいは暗色带 などの部分よりもよりすぐれた鍵層として確認したから である．このガラス密集帯の直上にくる $\mathrm{S}_{1} \mathrm{~S}$ むい鍵層 となる. 一枚の特異な, つまり他の層準のテフラから識 別されるテフラの認識とその追跡は，土壤化したテフラ 層の集合層である暗色帯などよりも，より優位の horizon marker であることはいうまでもないからである.

さて，このようにみると，小林の指摘するナイフ型石 器の出現する層準が, 上述の TnP をはさんで, 月見野, 野川雨遺跡で前後するのは，どのように説明したらよい であろうか. 一つの妥協的な案としては，その間にはさ まれる鍵層の $\mathrm{Tn} \mathrm{P}$ と $\mathrm{S}_{1} \mathrm{~S}$ およびそれらに近い層準のテ フラは堆積が早かったとし, 両層準はこれらのテフラを はさむものの，時間的な隔たりはさほど大きくないか もしれない，という解噃を下すことである.たしかに， 鍵層の一つである $\mathrm{S}_{1} \mathrm{~S}$ は立川口ームの中では厚いスコリ アであるので, この部分の堆積速度は早かったと考えら れる. しかし, 詳しくみると, 野川ではナイフ型石器の 産出層 $\mathrm{N}-4$ 層は，ガラス極大層準から約 $40 \sim 50 \mathrm{~cm}$ 上 位にあり，その間に第一暗色帯と呼ばれる腐植質火山灰 層をはさむ。また月見野では，小林のいうナイフ型石器 は，TnP の劂準から $20 \mathrm{~cm}$ ほど下位にある腐植質火山 灰層 (BB-3) から出土する. 産出層が 1 枚ないし数枚の テフラしか隔てていないものならば，その時間の間隔は 少ないとみることができよう. しかし，相当多数のテフ 
ラ層からなる風化した腐植質火山灰層をはさんでいると ころからみると，両層準の隔りはかなり大きいと判断さ れる. 安易な妥協は排すべきであろう.

さて, 石器については全くの素人である筆者にとって， 野川の N-4 層から出土するものと, 月見野の BB-3 から出土するものとが，同一型式，同一時代とする小林 ・小田の意見を諭評することは不可能である・ただ筆者 らの論交の III．2の末尾でのべた原因の考察の中でと くに考古学側に敢て希望を述べるとすれば，問題となる 層準で tool-kit が完全に出揃っているか否かの検討とい う点である. 石器の型式による対比でつよく要請される のは，いうまでもなくより豊富な tool kit の出土という 条件であると考えられる. この条件汪野川，月見野雨遺 跡の，立川ロームすべての層準ではたして满たされてい るであろうか. したがってこの点はとくに月見野のBB3 以下，野川のV層以下で，チェックされることがのぞ まれる。

以上，小林氏の討諭に対して，テフロクロノロジーの 立場から答えた．結局は諭評とこの答えとの間では，而 者それぞれの立場からの主張をくり返し，結局は平行線 を辿ることになったわけであるが，こ礼を契機として， さらに多くの研究者の広い分野からのアプローチと討 諭が行なわれることが期待される. 筆者も, 今後 TnP を含め，それと同様の重要性をもつテフラとその特性を 見出すことに努め，より詳しくより正確な編年の手がか りを得たいと考えている。 むちろえ考古学的事実をない がしろにするつもりは毛頭ない。より高次のデータが得 られたときには，何らこだわることなく編年を改めたい と考えている. おわりに討論の契機を提供された小林氏

\section{木越邦彦氏の論評に答えて}

木越氏は，木炭の年代測定值が包含地層の可能な古い 年代值を与え，一方土壤有機物の測定值が地層の堆積年 代より一般に新しい值を与えることを示唆されるととも に，測定值はかなりの幅でとらえる必要のあることを指 摘された.これらによって，いくつかの測定值からテフ ラの堆積曲線を引く場合に，第 4 図に示した破線よりも 緩勾配の， $\mathrm{S}$ 図で深さ $6 \mathrm{~m} ， 3$ 万年の点を通る直線を引 く方が妥当ではないかと論ぜられた。

この図のように，性質の異なる試料が混じたわずか数 点の, しかもそのばらつきの大きい年代測定值から, 堆 積曲線を引くには，相当の任意性が入ることは確かであ
に謝意を表したい。

\section{2. 田尻貞治氏の論評に答えて}

1) 対比の論拠を明示するべきだという主張には無部 賛成する. テクロクロノロジ一の場合，1枚の単層（1 噴火輪廻の噴出物）の岩石 ·鉱物学的, 物理 ·化学的, そして粘土鉱物学的な，あらゆる諸特徵を記載しておく ことが, 各地の対比, ことに火山から遠い地域での対比 と, 水成層と陸成層の対比の基礎になるものと考えられ る.

2) 給源火口から風下域の遠隔地までの，テフラの岩 相変化を示した第 3 図は, 実際に富士火山の新期テフラ, 古期テフラのスコリアを，一枚一枚追跡した結果から得 られた「モデル」である.こうした岩相変化がなぜ起る かについては，テフラの一次的な降下・堆積条件（原初 の擪さの分布）とその後の風化および土壤化の経過に負 っていると考える. 問題は, 本文にのべたように, 現実 に存在するテフラの種々の岩相から，いかなる古環境が どれほど卓越して，その形成に関与したかを導き出すこ とにある。

3 ）立川口ームの暗色帯が一律に暖期に形成されたと は，筆者は考えていない，ただ表層のクロボク土壤に 関して山, 従来の諸説と同じく, 後氷期の気候・植生条 件がつよくその形成に関与したことは否定できない.

2 ）でのべたように，立川ロームの暗色帯については気 候・植生条件以外にテフラの堆積条件も十分考虑する必 要があると考えている. その意味でテフラないしそれに 関連する地層の花粉分析や年代測定は重要であると考え ている.

町田洋 - 宮 崎 明子

Hiroshi MaGhIDA and Akiko MrYazaki

る. 第 4 図の破線は, 年代測定值を基準とし, 個々の試 料の性格に由来する值の意味も考虑して, なるべく矛盾 の少ない第一次近似的な意味をもつ線として引いたもの である.なお年代值以外にテフラの堆積状態, 土器など 考古学的試料の層準などからの判断も加えてある. 地層 の堆積年代に近いと考えられる木炭の年代值がわずか 2 点にすぎないので，これに忠実に引くと 2 万年前のころ 堆積速度は著しく早いように引かざるをえず，しかも土 壤有機物の年代測定值に適合させて引くなら，複雑な曲 線とならざるをえない，測定例の少ない現段階では，そ こまで論ずることは不可能であろう．一方，木越氏の引 いた紱勾配の直線とすると，3つの土壤有機物の年代值 
が期待とは反して古い方へかなりずれる. 第4 図の破線 の方が，同様の矛盾はあるものの，僅かに小さいように みえる. 実際には，多くの矛盾を消去するようなテフラ の堆積曲線は描きにくいのが現状である. 今後, 測定例 が増すにつれて, 問題点とともに, 多くの知見のえられ ることが期待される.

次に, 第 4 図で筆者らは, 約 1 万年前以降テフラの堆 積速度が急に遅くなったように示したことについて，木 越氏は，むしろ立川口ームから 1 万年前以降も含めて堆 積が等速であったと解釈した方がよいという見解を示さ れた・たしかに，木越論評の 1) と 2）に述べられた諸 点を勘案の上, 図示した測定值のみに基づいて堆積曲線 を引くなら,そのように引くのが妥当であろう.しかし， 筆者らが第 4 図において，1 万年前ごろから堆積が遅く なるように破線を引いたのは，ここに示した ${ }^{14} \mathrm{C}$ 年代值 のみでなく，次の諸点を考虑したからである. 1) 相模 野でも武蔵野であ, 表土の黒土層の下限近くからは, 従来 南関東各地でほぼ 1 万〜 9 千年前という ${ }^{14} \mathrm{C}$ 年代値のえ られている繩交早期初頭の土器が出土すること. 2) 火 山に近い富士東麓〜相模野では，立川口ームの最上部は 粗粒の赤褐色スコリアであるが，その上でかなり急に岩 相が変り，細粒の黒褐色腐植質火山灰となること．この 腐植質火山灰層は富士山麓で富士黒土層と呼ばれ，富士 火山の古期活動と新期活動とを隔てる活動静稳期に, ご くゆっくりと降下した細粒火山灰を母材とするものであ

\section{1. 下末吉・武藏野ローム中の黑曜石に黑曜石年代測 定法を適用できる可能性について}

フィッション・トラック法による年代測定が行われた テフラ中の 黒曜石に 黒曜石年代 測定法を 適用すること は, 理論的には可能であるう. 最近, 町田洋 - 小野昭両 氏と箱根周辺のテフラを調査した折，TP (東京パミス), OP (小原台パミス) 等に含まれる黒曜石を採取したの で，測定を試みる予定であるただその結果の解釈には 次のような問題を考慮する必要があろう. (1)町田・鈴木 （1971）に述べたように，テフラ中の黒曜石は，変質が はなはだしいものが多く，フィッション・トラック法に よる年代測定可能な試料が極めて少ない，この事実は， 同一テフラに由来する黒曜石でも,かなり質的に異なり， その結果水和速度自体にも，それぞれかなり变異がある と考えられる. したがって，こうして得られた標準検量 線の内挿から得られる先土器時代遺跡の黒曜石年代が,
る(町田：1964). この中には繩文早期から前期までの 土器が含をれる. 3) 相模野・武蔵野の表土の黒土は, この富士黒土層とその上にのる新期テフラとが土壤化し たものであるが, 後者の場合も古期テフラに比べて 1 噴 火輪廻の噴出物は少量で，ややゆっくりと堆積したと考 えられること.

以上の点は，1万年前以降の黑土が，立川ロームとそ の中に含まれる暗色帯に比べて特異なものであることを よく物語るものと考えられる. 腐植含量が著大であるこ とは, 従来の黒土成因説のように, 後水期の気候・植生 の影響，さらに人為的な植生の改変なども大いに関係す るにちがいないが, 一方では, 母材とのものの堆積速度 が微弱となったこと, 細粒であることなども関与してい ると考えられる.

なお, 立川ロームと黒土層の境界の年代は, 場所によ り多少異なるであろうことは予想されるが，相模野・武 蔵野に打ける具体的な資料はまだ提示し得ない。また， 木越氏ののベる二次的な風送によるローム——多分, 一 度堆積したテフラが再移動したり, テフラ以外の風塵の 混入したロームという意味であろう一一の分量は，給源 火山から遠くなるにつれて多くなるように思える。それ を裏づけるような混入物も知られてはいるが，相対的に 少量で, 各地の堆積速度に変化を与えるようなことは, あってもごく局地的にしかみられないであろう.

\section{鈴 木 正 男 Masao Suzuki}

精緻な組み立てを要求し，かつ行うことを目指している 考古学の方法論に寄与しうるかどうかはかなり疑問であ る. (2)下末吉・武蔵野ロームから立川ロームにかけての 時代には Würm 氷期の到来, ポードルフ，ゲトワイゲ ル覀間水期の存在等が証拠だてるように，かなり大きな 気候変動が介在しているから，同一地点の上下層準間で も， $\mathrm{T}=\mathrm{aL}{ }^{2}$ が成立するかどうか吟味することが必要で ある.

以上の理由で，黒曜石年代測定法をテフラ由来の黒曜 石に適用した結果の解釈には慎重でなければならない。 筆者の考えるところでは，これより更に有効であろう方 法は，遺跡から出土する焼けた黒曜石のフィッション・ トラック年代(Watanabe and Suzuki : 1969) の測定と, 同一層由来の焼けていない黑曜石の黑曜石年代測定を組 み合せることである、（焼けた黒曜石の水和速度は，か なり阻害されているから，正しい測定值は焼けていない 
黒曜石から得る必要がある.). 実際, 武蔵野台地先土器 時代遺跡の二・三から，そうした焼けた黒曜石が発見さ れ, 現在フィッション・トラック法による年代測定を行 ないつつあるので, 近い将来報告できるものと思う.

とまれ，黒曜石の水和の機序が明らかになれば，テフ ラ由来の黒曜石の水和層測定值は, 逆にその時代の気候 の推定に役立つ可能性がある. そうした意味で, 現在試 料採取・測定を行なっている.

\section{2. 水和首測定の方法について}

水和層測定の方法については, Friedman and Smith (1960), Katsui and Kondo(1965) と大差ない. これら の詳しい方法論の検討は, 近い将来, 別の論文で行う予 定である.

\section{3. $\mathbf{T}=\mathbf{a L}^{2}$ の成立について}

一様な環境条件，黒曜石の内的条件のもとでは， $\mathrm{T}=$ $\mathrm{aL}^{2}$ が成立することは，理論的にも，経験的にも十 分当を得ている (Friedmanand Smith : 1960). ただ, Katsui and Kondo (1965) が示したように，約 5,000 年 B. P. の繩文海進（有楽町海進）の現在よりも温暖で あったとされる時代を境として，それ以前では，水和速 度が 鈍化することは原理的にもあり得ることである.
Friedman and Smith (1960) が設定した検量線は地域 により, 現在から 4,000 B. P. 〜 9,000 B. P.の年代範 囲であり，かつ年代既知層準由来の試料点数が 少なか ったために，この気候の寒冷化にともなうう水和速度の 鈍化を明らかにすることができなかったのであろう．幸 いにも，我が国は，黒曜石を豊富に産出し，かつ洪積世 （1.1 万年 B. P. 以前）の遺跡が多数発見されつつあるか ら，この黒曜石年代測定法の多角的な適用は，極めて豊 かな結実をみるものと予想される。

以上述べたように黒曜石年代測定法は，方法論自体に 未だ不確定要因が多く，それらは全て今後の研究を待つ ものである. シミュレーションによって水和層を実験的 に形成して，因子分析をすることなどを通して，これら の不確定要因を解決していくことが急務であろう.

最後に，コメントを寄せていただいた方々に，この方 法の発展のために特に記して感謝の意を表する.

\section{引用交献}

Watanabe, N. and M. Suzuki (1969) Fission track dating of archaeological glass materials from Japan. Nature, 222, 1057-1058. 